\title{
Time-dependent C5a and C5aR expression in dental pulp cells following stimulation with LTA and LPS
}

\author{
MINGYUE LIU ${ }^{1,2^{*}}$, HAIBIN MU ${ }^{3 *}$, WENTING PENG ${ }^{4}$, LIN ZHAO $^{4}$, WEIPING HU ${ }^{1}$, \\ ZHULING JIANG ${ }^{5}$, $\mathrm{LI} \mathrm{GAO}^{6}$, XIAOFANG CAO ${ }^{7}, \mathrm{NING} \mathrm{LI}^{8}$ and JINGYING HAN ${ }^{9}$
}

${ }^{1}$ Department of Prosthodontics, The Second Affiliated Hospital of Harbin Medical University, Harbin, Heilongjiang 150086,
P.R. China; ${ }^{2}$ Bioscience Research Center, University of Tennessee Health Science Center, Memphis, TN 38163 ,
USA; ${ }^{3}$ Department of Radiology, The Second Affiliated Hospital of Harbin Medical University, Harbin,
Heilongjiang $150086 ;{ }^{4}$ Department of Stomatology, Dezhou People's Hospital, Dezhou, Shandong $253000 ;$
Departments of ${ }^{5}$ Oral Implantology, ${ }^{6}$ Oral and Maxillofacial Surgery, ${ }^{7}$ Endodontics, ${ }^{8}$ Cardiology, and ${ }^{9}$ Orthodontics,
The Second Affiliated Hospital of Harbin Medical University, Harbin, Heilongjiang 150086, P.R. China

Received February 21, 2019; Accepted June 11, 2019

DOI: $10.3892 /$ ijmm.2019.4246

\begin{abstract}
Clinically, deep decay can lead to inflammation in the dental pulp. Apart from the use of various materials to sooth the inflamed pulp, there is currently no adequate treatment, and the gold standard, calcium hydroxide, that is used to cover the dentin/pulp, has limited effect. Sometimes the pulp will remain infected and cause pulpitis, and ultimately, the pulp will need to be removed. The first principle of oral treatment is to protect the pulp. Therefore, it is necessary to study the immune response and regeneration of pulp cells in conditions of deep decay. Of the terminal complement system proteins, complement $5 \mathrm{a}(\mathrm{C} 5 \mathrm{a})$ has the most potent effect compared to complement $3 \mathrm{a}(\mathrm{C} 3 \mathrm{a})$ and complement $4 \mathrm{a}(\mathrm{C} 4 \mathrm{a})$. $\mathrm{C} 5 \mathrm{a}$ is 20- to 2,500-fold stronger than $\mathrm{C} 3 \mathrm{a}$ and $\mathrm{C} 4 \mathrm{a}$. The purpose of this study was to elucidate the association between C5a, secreted by complement activation, and the duration of inflammation. Another key goal was to detect the expression of $\mathrm{C} 5 \mathrm{a}$ and its receptor, complement 5a receptor (C5aR). To this end, the cells were divided into 4 groups as per stimulation with lipoteichoic acid (LTA) or lipopolysaccharide (LPS) as follows: i) The $1 \mu \mathrm{g} / \mathrm{ml}$ LTA group; ii) the $1 \mu \mathrm{g} / \mathrm{ml}$ LPS
\end{abstract}

Correspondence to: Dr Ning Li, Department of Cardiology, The Second Affiliated Hospital of Harbin Medical University, 246 Xuefu Road, Harbin, Heilongjiang 150086, P.R. China

E-mail: drlining@163.com

Dr Jingying Han, Department of Orthodontics, The Second Affiliated Hospital of Harbin Medical University, 246 Xuefu Road, Harbin, Heilongjiang 150086, P.R. China

E-mail: jingying5787@163.com

${ }^{*}$ Contributed equally

Key words: complement 5a, complement 5a receptor, interleukin-6, dental pulp cells, lipoteichoic acid, lipopolysaccharide group; iii) the $1 \mu \mathrm{g} / \mathrm{ml}$ LTA and $1 \mu \mathrm{g} / \mathrm{ml}$ LPS group; and iv) the PBS-only group, which served as a control. There were 5 time points for all 4 groups: 1, 2, 3, 5 and 7 days. Reverse transcription-quantitative polymerase chain reaction was used to detect the gene expression levels of C5a, C5aR and interleukin (IL)-6 at different time points. Western blot analyses was carried out to detect the expression of C5aR. Transmission electron microscopy was also conducted to assess the ultrastructural features of dental pulp cells. The gene expression trends of C5a and C5aR mRNA were identical. C5a and C5aR mRNA was highly expressed on the second day of LTA or LPS stimulation. However, in the LTA and LPS co-stimulation group, C5a and C5aR mRNA were highly expressed on both the first and second day, with higher levels on the second day. IL-6 expression decreased as time progressed in the LTA only and in the LTA + LPS co-stimulation groups. However, a peak in its expression was observed on the second day in the LPS group. On the whole, this study demonstrates that a $1 \mu \mathrm{g} / \mathrm{ml}$ concentration of LTA and LPS stimulates human dental pulp cells to activate the expression of C5a.

\section{Introduction}

Clinically, tooth decay can be easily neglected, and it has usually already affected the pulp when symptoms appear. A common treatment for this is often to remove the pulp. Sometimes the pulp inflammation is mild, although the pulp remains necrotic. It seems that once decay has invaded the pulp, the pulp's self-repairing ability is not strong enough to combat its effects. A number of studies $(1,2)$ have confirmed that pulp contains highly active and differentiated dental pulp mesenchymal stem cells, which are a type of somatic stem cells, and the proliferative and repair regeneration abilities of dental pulp stem cells are stronger than those of bone marrow stem cells. However, it remains to be elucidate as to why dental pulp cells are not able to resist foreign pathogens, and eventually necrosis, when the pulp becomes inflamed. Researchers are investigating effective methods with which to 
prevent caries from further invading the pulp. Clinically, some indirect capping materials are used to maintain pulp vitality that is considered to encroach on the pulp. Studies have shown that the process of repairing dentin can be induced following mitigation (3-5). However, the process of repair and regeneration is actually an immune process. Firstly, relatively low levels of inflammatory molecules are released from the soft and hard tissues of the teeth. In the meanwhile, the addition of antioxidants, such as N-acetyl cysteine (NAC) to the Anga material can limit the activity of the nuclear factor $(\mathrm{NF})-\kappa \mathrm{B}$ proinflammatory pathway by upregulating the p38 mitogenactivated kinase signaling (MAPK) signaling pathway, and thus releasing the corresponding cytokines (6). This process plays an important role in minimizing the inflammatory response of the pulp. Therefore, it provides a more favorable environment for promoting dental hard tissue repair.

As is well known, following inflammation and tissue damage, the complement system immediately provides the signals needed to eliminate invaders and alter host cells. The activation of the complement system occurs primarily through infection; however, it can also be initiated through trauma. Following complement activation, a series of complementary protein fragments with important biological effects, such as C3 convertase, C5 convertase, complement 3a (C3a), complement $3 b(\mathrm{C} 3 \mathrm{~b})$, complement 4b (C4b), complement 5a (C5a) and complement $5 \mathrm{~b}(\mathrm{C} 5 \mathrm{~b})$ are formed (7). C3a, C4a and C5a can cause the degranulation of basophils/mast cells and a higher release of histamine, serotonin and vascular active mediators (8-15). Subsequently, these indirectly alter the vascular permeability and thereby cause the inflammatory response. $\mathrm{C} 5 \mathrm{a}$ is a protein fragment released from the cleavage of complement component $\mathrm{C} 5$ by protease $\mathrm{C} 5$-convertase into C5a and C5b fragments. C5b deposits on the surface of the pathogen, and $\mathrm{C} 5 \mathrm{a}$ is then released into the liquid phase. As an anaphylaxis, C5a has the most potent effect compared to $\mathrm{C} 3 \mathrm{a}$ and $\mathrm{C} 4 \mathrm{a}$. C5a is 20- to 2,500-fold stronger than C3a and $\mathrm{C} 4 \mathrm{a}$ (16). For this reason, we selected to C5a for investigation in this study. Complement activation protects the body against foreign pathogens. However, sometimes it can damage the body via an overactive immune system as described above.

In addition, the risk of developing local and distant organ failure following complement activation depends on the levels of circulating anaphylatoxins and terminal complement complex levels, and the duration of complement activation (17). Patients with extensive tissue damage and massive complement activation are prone to uncontrolled inflammatory reactions and subsequent multiple organ dysfunction syndrome (MODS) (18). On the other hand, clinical trials with experimental animals in trauma with complement depletion, complement deficiency, or the administration of exogenous complement inhibitors have demonstrated that the response of important organs to inflammatory stimuli is significantly reduced and has a protective effect (19-24). These trials confirm the important role of complement in the inflammatory response caused by trauma from the opposite side of the inflammation-repair continuum. Therefore, an uncontrolled inflammatory response can lead to pathological damage. Studies have shown that C5a is involved in the inflammatory response mainly through the $\mathrm{C} 5$ a receptor (C5aR) of inflammatory cells. Therefore, blocking the interaction between $\mathrm{C} 5 \mathrm{a}$ and
C5aR is expected to inhibit its inflammatory response $(17,18)$. High concentrations of C5a act as chemotactic agents for related immune cells, and can induce immune cells to move in the direction of the concentration gradient of C5a, such as neutrophils, eosinophils, and monocytes (19). High concentrations of C5a can also stimulate the oxidative metabolism of neutrophils and monocytes, increase the level of cGMP, promote the fusion of lysosomes and cell membranes, and release lysosomal enzymes. In addition, C5a also has the effect of enhancing the immune response, specifically to induce the secretion of interleukin (IL)-1, IL-6, IL-8 and tumor necrosis factor (TNF) $-\alpha$ by monocytes (22), and promotes $\mathrm{T}$ cell proliferation and $\mathrm{B}$ cell production of antibodies. C5a can be activated by binding to its corresponding receptor $\mathrm{C} 5 \mathrm{aR}$, and it is involved in the pathological development processes of a number of inflammatory diseases, such as cisplatin-associated glomerulonephritis (16), rheumatoid arthritis (25), acute lung injury (26,27), pyemia (21) and cardiovascular diseases, such as atherosclerosis (24) and the formation of tumors (23). Research on the liver have shown that $\mathrm{C} 5 \mathrm{a}$ is involved in liver tissue regeneration and is highly regenerative (28). When the livers of C5-deficient mice are damaged by toxins, their livers cannot be regenerated when treated with CCL4/chemokines. However, liver regeneration can be observed after injecting C5 or C5a into the treated animals (29). This effect of C5a can also be found in cardiac tissue regeneration (30). C5a is not only induced by the implanted progenitor cells, but also promotes the differentiation of progenitor cells. Following fractures in humans, it has been found that there is a significant increase in C5aR expression in mesenchymal progenitors during osteogenic differentiation (31). This also indicates that C5a induces the migration of mesenchymal progenitor cells, and that $\mathrm{C} 5 \mathrm{a}$ is involved in broken bone regeneration. In recent years, it has been found that C5a is associated with dental pulp inflammatory diseases (32-37).

Decay, trauma, and the stimulation of filling material may cause inflammation in the dental pulp. While severe tooth decay often leads to pulp necrosis, under mild/moderate carious decays, a dentin bridge can be observed in vivo, which protects the healthy pulp and separates it from bacterial invasion $(37,38)$. During the progression of caries, odontoblasts are the first cells to face bacteria and their toxins. Following the stimulation of decay, the dentin is demineralized, and the released signal molecules in the dentin matrix are dispersed into the dental pulp cells, so that the secretion activity of the odontoblasts is stimulated, the activity of the odontoblasts is upregulated, and reactive dentin is synthesized, thereby preventing bacteria and their toxins from invading the pulp. With deep caries, which extend close to or into the pulp, the fibroblasts in pulp are stimulated and increase its synthetic capacity. This includes the synthesis of complement proteins and activation of the complement system to recruit progenitor cells required for the establishment of dentin bridges. The soluble fragments $\mathrm{C} 3 \mathrm{a}, \mathrm{C} 4 \mathrm{a}$, and $\mathrm{C} 5 \mathrm{a}$ produced following complement activation modify the vascular permeability indirectly via the induction of basophiles/mastocytes degranulation. This subsequently leads to a massive liberation of histamine and serotonin, which increases vascular permeability. $\mathrm{C} 3 \mathrm{a}, \mathrm{C} 4 \mathrm{a}$, and $\mathrm{C} 5 \mathrm{a}$ also act on endothelial cell permeability by inducing fiber stress formation, which 
facilitates leukocyte diapedesis upon contraction. The created gradient of these fragments guides leukocyte migration toward the infected/inflamed tissue. In parallel, C5a activates pulp progenitor cells, and the produced C5a gradient guides their migration toward the injured tissue to initiate the dentin-pulp regeneration process (34). This clearly shows that any local tissue repair directly leads to dentin pulp regeneration. It has been reported that the loss of complement activation is linked to early dentin pulp regeneration. Dental pulp fibroblasts can be used as non-immune cells with cells that synthesize all complement proteins and secondary complement activation (33). It has been demonstrated that $\mathrm{C} 5 \mathrm{a}$ is involved in the early stage of dentin pulp regeneration; that is, the selective recruitment reaction of dental pulp progenitor cells to the $\mathrm{C} 5 \mathrm{a}$ product site responds to a certain gradient (36). Tooth repair and regeneration require odontoblasts, which can synthesize mineralized tissue in dentinal tubules or around pulp wounds (called reactive/restorative dentin). This protects the pulp from invading bacteria. Over the past 5 years, the number of studies on C5a have increased. The study group of I. About (Chmilewsky et al) published several articles in the Journal of Dental Research on the involvement of C5a in pulp inflammation and complement activation. They proposed that the largest proportion of fibroblasts in dental pulp cells is made up of non-immune cells with cells that synthesize all complement proteins and provide secondary complement activation (33). The recruitment of dental pulp mesenchyme stem cells induce by C5a is an essential step in dentin pulp regeneration. In addition, the study group of I. About presented a hypothesis of the initiation of dentin-pulp complex regeneration arising after the elimination of cariogenic bacteria, or at least after the prevention of further progression of rickets (37). Therefore, complement activation causes inflammation and regeneration to occur simultaneously in the pulp.

It is well known that bacteria are closely related to the onset of dental caries (33). Bacteria are divided into Gram-negative and Gram-positive species. Most pulp inflammation is caused by the development of dental caries (36). Gram-positive bacteria consists of a thick, dense peptidoglycan and teichoic acid. Teichoic acid is a specific component of Gram-positive bacteria. It is interspersed in peptidoglycan in a long-chain form. One end is bound to the cell wall as wall phosphate (WTA), and the membrane or lipoteichoic acid (LTA) is bound to the plasma membrane. Gram-negative bacteria consist of a lipopolysaccharide (LPS)-lipoprotein-phospholipid outer membrane that surrounds a thin peptidoglycan layer and does not contain teichoic acid. Gram-positive cocci can destroy organic matter, and the teeth can form cavities after long-term action (2); while the acid-producing bacteria are Gram-negative bacteria, which can decompose carbohydrates to produce acid, which leads to demineralization of dental minerals (39). Along with the development of caries, the proportion of bacteria in plaque can change continuously $(32,34)$. Both LTA and LPS act as antigens, and activate immune cells to secrete many inflammatory factors (40-42). There are some studies available which have used LTA or LPS to stimulate dental pulp cells $(32,34,35,42)$. Although LTA has been less often reported than LPS, the activation of LTA and LPS as antigens is the same for immune cells. Therefore, we use both of them to detect the immune response. The inflammatory response of cells requires the activation of intercellular signaling pathways, including the transcription factors nuclear factor (NF)- $\kappa \mathrm{B}$ and also those of the mitogen-activated protein kinase (MAPK) family, for example extracellular signal-regulated kinase (ERK), JNK and p38. Cytokines that are typically produced by fibroblasts upon pro-inflammatory stimuli, such as IL-6 and IL-8. Notably, IL- 6 and IL- 8 are associated with pulpal inflammation in caries exposure (43). Thus, the expression of IL-6 or IL-8 can indicate inflammation of the cells.

It would be of interest to determine the effects on the secretion of C5a when inflammation occurs and invades the pulp. Thus, in this study, we aimed to detect the expression of C5a and its receptor $\mathrm{C} 5 \mathrm{aR}$. Therefore, based on the role of $\mathrm{C} 5 \mathrm{a}$ in the regeneration of other organs and pulpitis, the objective of this study was to examine the presence of C5a, C5aR and IL-6 in inflamed pulps and to attempt to elucidate its role in dental pulp inflammation.

\section{Materials and methods}

Primary pulp cell cultures. Human pulp cells were prepared from immature third molars at the $2 / 3$ root formation stage by the explant outgrowth method (2). The teeth were obtained from at least 3 different donors for each experiment ( $n=12$; 4 molars per donor; age, 18-25 years; ratio, 1:1 male to female). Surgeries were performed at the Oral and Maxillofacial Surgery Department of The Second Affiliated Hospital of Harbin Medical University. The present study was approved by the Institutional Ethics Committee of The Second Affiliated Hospital of Harbin Medical University. Written informed consent was obtained from all patients. The basic cell culture medium used consisted of Dulbecco's modified Eagle's medium/F-12 (HyClone; GE Healthcare Life Sciences), supplemented with $15 \%$ fetal bovine serum (Biological Industries) and $1 \%$ penicillin and $1 \%$ streptomycin (Beyotime).

Induction of dental pulp cell differentiation into adipocytes, chondroblasts and osteoblasts. The cells were cultured to the third generation in a $37^{\circ} \mathrm{C}$ incubator with $5 \% \mathrm{CO}_{2}$. All groups of cells were plated at a density of $1 \times 10^{5}$ per well. To induce dental pulp stem cells (DPSCs) to differentiate into adipocytes, the culture medium was supplemented with $0.5 \mu \mathrm{M}$ 3-isobutyl-1-methylxanthine, $50 \mu \mathrm{M}$ indomethacin and $0.5 \mu \mathrm{M}$ dexamethasone for 3 weeks. The adipogenic cultures were fixed in $4 \%$ paraformaldehyde for $30 \mathrm{~min}$ at room temperature and stained with fresh Oil Red O solution (Sigma-Aldrich) for $1 \mathrm{~h}$ at room temperature. The chondroblast induction medium consisted of $1 \mu \mathrm{M}$ dexamethasone, $37.5 \mu \mathrm{g} / \mathrm{ml}$ vitamin C-phosphate, $1 \mathrm{mM}$ sodium pyruvate, $10 \mathrm{ng} / \mathrm{ml}$ transforming growth factor- $\beta$ (TGF- $\beta$ ), $1 \mathrm{ng} / \mathrm{ml} \beta$-fibroblast growth factor $(\beta$-FGF), 1X Insulin-Transferrin-Selenium premix (Sigma-Aldrich; Merck KGaA), in which the DPSCs were maintained for 3 weeks. The chondrogenic cultures were fixed in $4 \%$ paraformaldehyde for $30 \mathrm{~min}$ at room temperature and stained with toluidine blue (Toluidine Blue O Cartilage Stain solution, Solarbio Life Sciences) for $30 \mathrm{~min}$ in a $37^{\circ} \mathrm{C} \mathrm{incu-}$ bator. The osteoblast induction medium contained $10 \mathrm{nmol} / \mathrm{l}$ dexamethasone, $5 \mathrm{mmol} / \mathrm{l} \beta$-glycerophosphate and $50 \mathrm{mg} / \mathrm{ml}$ 
vitamin C-phosphate, in which the DPSCs were cultured for 3 weeks. The osteoblast cultures were fixed in $95 \%$ ethanol for $30 \mathrm{~min}$ at $37^{\circ} \mathrm{C}$ and stained with Alizarin Red S (SigmaAldrich) for $30 \mathrm{~min}$ in a $37^{\circ} \mathrm{C}$ incubator. The cells were observed under a light microscope (ZEISS, 37081 Goettingen, Germany) (original magnification, $\mathrm{x} 40$ ).

Cell groups and culture conditions. The third generation

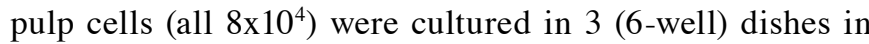
a $37^{\circ} \mathrm{C}$ incubator with $5 \% \mathrm{CO}_{2}$. Prior to grouping, the cells were washed 3 times with PBS and then incubated in serumfree DMEM ( $2 \mathrm{ml} /$ well) for $24 \mathrm{~h}$. The cells were cultured by $1 \%$ penicillin and $1 \%$ streptomycin, serum-free DMEM, and divided into 4 groups as follows: i) The $1 \mu \mathrm{g} / \mathrm{ml}$ LTA (SigmaAldrich) group; ii) the $1 \mu \mathrm{g} / \mathrm{ml}$ LPS (Sigma-Aldrich) group; iii) the $1 \mu \mathrm{g} / \mathrm{ml} \mathrm{LTA}$ and $1 \mu \mathrm{g} / \mathrm{ml}$ LPS group; and iv) the PBS-only group as control. There were 5 time points for all 4 groups: 1, 2, 3, 5 and 7 days. The re-addition of equal concentrations of LTA stimulant for each change.

Cytotoxicity (MTT) assay. The present study employed 96-well plates with $1 \times 10^{3}$ cells/well. Dimethyl sulfoxide $(200 \mu 1)$ was added to dissolve the formazan crystals. The absorbance was measured with an ELISA reader (Thermo Fisher Scientific, Inc.) at a wavelength of $490 \mathrm{~nm}$. The cell viability ratio was calculated using the following formula: Inhibitory ratio $(\%)=$ [optical density (OD) control-OD treated)/ (OD control)] x100.

Reverse transcription-quantitative polymerase chain reaction (RT-qPCR) analysis. All groups of cells were cultured in mineralized solution (in a $37^{\circ} \mathrm{C}$ incubator with $5 \% \mathrm{CO}_{2}$ ) and total RNA was extracted on days $1,2,3,5$ and 7 to detect the gene expression levels of C5a, C5aR and IL-6. Total RNA was extracted using TRIzol reagent (Invitrogen; Thermo Fisher Scientific, Inc.) according to the manufacturer's instructions. Subsequently, the RNA was converted into cDNA using a Transcriptor First Strand cDNA Synthesis kit (Roche Diagnostics $\mathrm{GmbH}$ ) using the following temperature protocol: $50^{\circ} \mathrm{C}$ for $60 \mathrm{~min}, 85^{\circ} \mathrm{C}$ for $5 \mathrm{~min}$ and $4^{\circ} \mathrm{C}$ for $10 \mathrm{~min}$. The expression levels of the genes were quantified using FastStart Universal SYBR-Green Master Rox mix (Roche Diagnostics GmbH). The PCR thermocycling conditions were as follows: $95^{\circ} \mathrm{C}$ for $2 \mathrm{~min}$, followed by 40 cycles of $95^{\circ} \mathrm{C}$ for $15 \mathrm{sec}$ and $60^{\circ} \mathrm{C}$ for $30 \mathrm{sec}$. PCR results were normalized against the reference gene Actin to correct for non-specific experimental variation. The method of $\Delta \Delta \mathrm{Cq}$ was used to determine the relative quantity of mRNA expression in samples, and fold change was determined as $2^{-\Delta \Delta \mathrm{Cq}}$ (44). The following primers were used: C5a forward, 5'-GTTTGTCGT GGCTGTAGTCC-3' and reverse, 5'-GACCGCTTTCTGCTG GTGTTT; C5aR forward, 5'-CGTTTGTCGTGGCTGTAG TCC-3' and reverse, 5'-GACCGCTTTCTGCTGGTGTTT-3'; IL-6 forward, 5'-GCTCTGGCTTGTTCCTCACTA-3' and reverse, 5'-AATCATCACTGGTCTTTTGGAG-3; and actin forward, 5'-GGGAAATCGTGCGTGACATT-3' and reverse, 5'-GGAACCGCTCATTGCCAAT-3'.

Western blot analysis. Total protein was extracted from the 4 groups of cells on days 1, 2, 3, 5 and 7 using cell lysis buffer [20 mM Tris (pH 7.5), $150 \mathrm{mM} \mathrm{NaCl}, 1 \%$ Triton X-100,
$2.5 \mathrm{mM}$ sodium pyrophosphate, $1 \mathrm{mM}$ EDTA, $1 \% \mathrm{Na}_{3} \mathrm{CO}_{4}$, $0.5 \mu \mathrm{g} / \mathrm{ml}$ leupeptin, $1 \mathrm{mM}$ phenylmethylsulfonyl fluoride]. The lysates were collected by scraping from the plates and subsequently centrifuged at $15,000 \mathrm{x} \mathrm{g}$ at $4^{\circ} \mathrm{C}$ for $5 \mathrm{~min}$. The protein concentration was quantified using a bicinchoninic acid assay. Total protein samples $(20 \mu \mathrm{g} /$ lane $)$ were separated by $12 \%$ SDS-PAGE and transferred onto polyvinylidene fluoride membranes. The membranes were blocked in $1 \%$ BSA with $0.05 \%$ Tween-20 at room temperature for $2 \mathrm{~h}$. The membranes were then incubated overnight at $4^{\circ} \mathrm{C}$ with the following antibodies: Rabbit anti-human C5aR (1:200; cat. no. 21316-1-AP, Proteintech, Inc.) and $\beta$-actin (1:5,000; cat. no. 20536-1-AP, Proteintech, Inc.). The secondary antibody used were horseradish peroxidase-conjugated AffiniPure goat anti-rabbit IgG (cat. no. SA00001-2; Proteintech, Inc.) and goat anti-mouse IgG (1:10,000; cat. no. SA00001-1, Proteintech, Inc.). Bands were visualized using a Clarity $\mathrm{Max}^{\mathrm{TM}}$ Western ECL Substrate (Bio-Rad Laboratories, Inc.) and a Tanon 1000 digital image gel analytical system (Tanon Science \& Technology Co., Ltd.) was used for photography and quantification.

Transmission electron microscopy (TEM). The DPSCs were collected and fixed in $2.5 \%$ glutaraldehyde $0.1 \mathrm{M}$ cacodylate buffer ( $\mathrm{pH}$ 7.4) for $2-3 \mathrm{~h}$ at room temperature. The samples were post-fixed in $1 \%$ osmium tetroxide and dissolved in a $0.1 \mathrm{M}$ phosphate buffer $(\mathrm{pH}$ 7.4) for $1 \mathrm{~h}$ at room temperature. The samples were dehydrated in ethanol and embedded in Epon 812. Ultra-thin sections were contrasted in aqueous uranyl acetate and lead (II) hydroxide, observed and photographed using a Hitachi 7000 TEM.

Statistical analysis. All values are expressed as the means \pm standard error of the mean. Statistical analysis was performed by using one-way analysis of variance followed by Bonferroni multiple comparisons using SPSS 13.0 software (SPSS, Inc.). $\mathrm{P}<0.05$ was considered to indicate a statistically significant difference.

\section{Results}

Characterization of the differentiation potential of dental pulp cells in vitro. The presence of mineralized nodules demonstrated the successful osteogenic induction of DPSCs (Fig. 1A). As presented in Fig. 1B, the formation of neutral lipid vacuoles also indicated the adipogenic potential of the DPSCs. Furthermore, the DPSCs were observed to differentiate into chondroblasts following induction (Fig. 1C).

Cytotoxicity of LTA and LPS to the cells. The data for the control group revealed the highest level of cell proliferation among the 4 groups. The data for days 1 and 2 revealed no inhibition effect for all 4 groups. Beginning at day 3 , the cells in the LTA, LPS and LTA + LPS groups were less active than those of the control group (Fig. 2).

Cell state following stimulation with LTA and LPS on different days. The cultured cells were observed using a microscope. The cells in all the stimulated groups were observed to be in a healthy condition at day 1 (LTA alone in Fig. 3A, LPS alone in Fig. 3B, LTA and LPS co-stimulation in Fig. 3C). The 

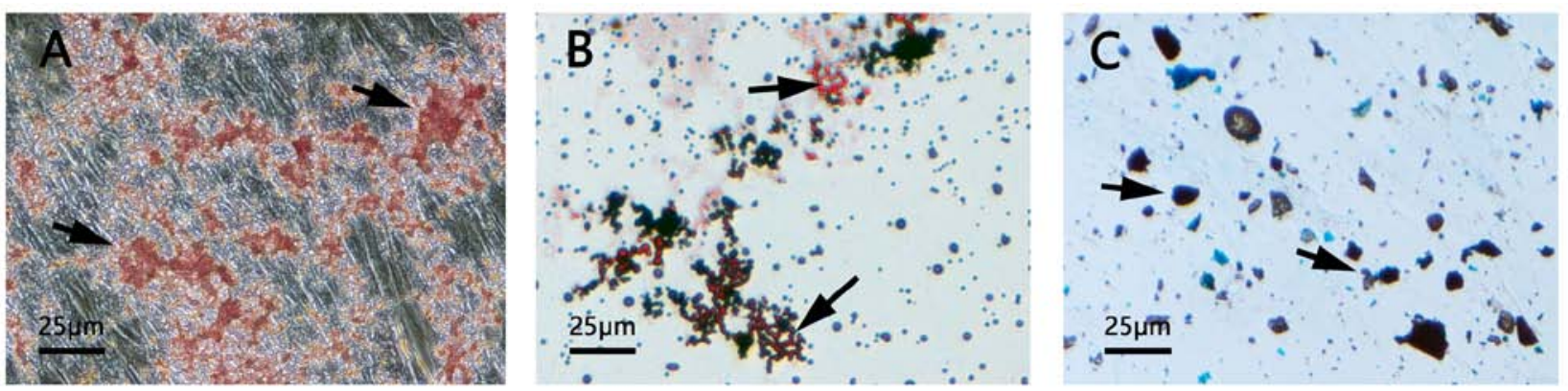

Figure 1. Multilineage differentiation capacity of dental pulp stem cells (original magnification, $\mathrm{x} 40$ ). (A) Osteogenic differentiation was indicated by the deposition of mineralized matrix, detected by Alizarin Red S staining. (B) Adipogenic differentiation was indicated by the accumulation of neutral lipid vacuoles, detected with Oil Red O staining. (C) Chondroblasts were detected by toluidine blue staining. Arrows indicate representative stained cells.

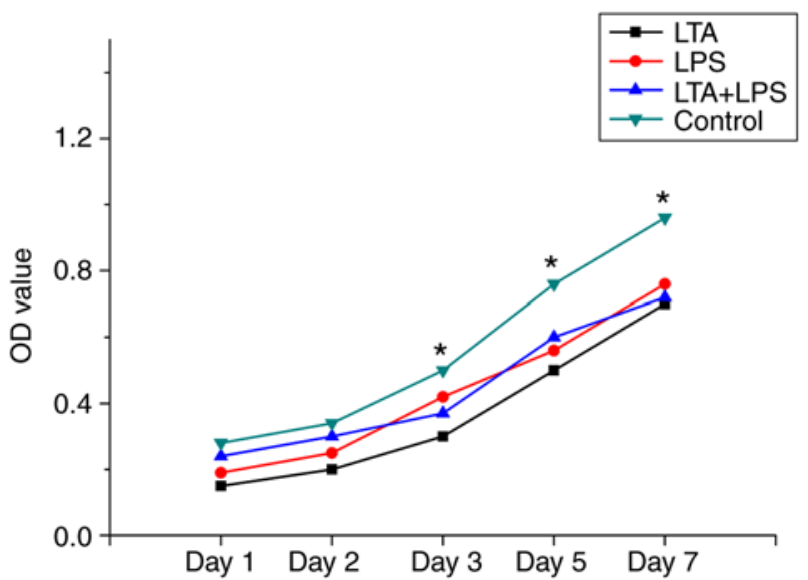

Figure 2. MTT assay. All groups underwent marked proliferation at days 1 and 2. The cell proliferation in LTA and LPS individual and combined groups was weaker than that in the control group. ${ }^{*} \mathrm{P}<0.05$ vs. the LTA group, LPS group, and LTA + LPS group at the corresponding time points. LTA, lipoteichoic acid; LPS, lipopolysaccharide.

cells in all the stimulated groups were still in good condition and a small amount of cell shrinkage was visible at day 2 (LTA alone in Fig. 3D, LPS alone in Fig. 3E, LTA and LPS co-stimulation in Fig. 3F). More cell shrinkage was observed at day 3 (LTA alone in Fig. 3G, LPS alone in Fig. 3H, LTA and LPS co-stimulation in Fig. 3I). It was observed that the cells had shrunk into pieces and their condition worsened at day 5 (LTA alone in Fig. 3J, LPS alone in Fig. 3K, LTA and LPS co-stimulation in Fig. 3L). The cell condition is not as good as the fifth day, the shrinkage is more serious, and floating dead cells are visible at day 7 (LTA alone in Fig. 3M, LPS alone in Fig. 3N, LTA and LPS co-stimulation in Fig. 3O).

Effects of LTA and LPS and their combination on C5a and C5aR expression in dental pulp cells. As shown in Figs. 4 and 5, the trends in the expression levels of C5a and C5aR mRNA were identical. In the LTA-stimulated group, it was observed that with the progression of the culture time and the continuation of stimulation, there was a significant change in the mRNA expression levels of C5a and C5aR. On the second day of stimulation, the expression levels of C5a and C5aR mRNA were increased, and the levels were 3 -fold greater than those observed at the other time points examined. The difference was statistically significant $(\mathrm{P}<0.05)$. However, no difference was observed between the expression of C5a versus C5aR mRNA. In the LPS-stimulated group, with the progression of the culture time and the continuation of stimulation, the expression levels of C5a and C5aR mRNA on the second day were 3-fold higher than those observed on the other days, and the difference was statistically significant $(\mathrm{P}<0.05)$. Apart from the second day, there was no significant difference in $\mathrm{C} 5 \mathrm{a}$ and $\mathrm{C} 5 \mathrm{aR}$ mRNA expression in the remaining days. In the LTA and LPS co-stimulated group, the expression levels of C5a and C5aR mRNA increased on the first day, which were 2-fold higher than those at 3 and 7 days, and the difference was statistically significant $(\mathrm{P}<0.05)$. The expression of C5a and $\mathrm{C} 5 \mathrm{aR}$ was the highest on the second day, which was 2-fold higher than that at 3 and 7 days. However, there was a rebound in expression on the fifth day. The difference was statistically significant $(\mathrm{P}<0.05)$. In addition, we examined the expression of IL-6 mRNA (Fig. 6). In the LTA-stimulated group, the high expression of IL-6 mRNA was observed on the first day, and the expression declined after the second day. However, the expression on day 7 increased again, the same as that at the first day. In the LPS-stimulated group, on the first day, IL-6 mRNA expression was low, and the expression increased the following day; on the third day, its expression decreased, and its expression on the fifth day was not altered. On the seventh day, IL-6 expression was slightly increased. Finally, in the LTA and LPS co-stimulated group, on the first day, IL-6 mRNA expression was highly expressed, then decreased a little on the second and third day. The expression of IL-6 mRNA subsequently decreased on the fifth day. However, no gene expression change was observed on the seventh day compared to the fifth day.

Protein expression of C5aR following stimulation with LTA and LPS and their combination. This experiment examined the protein expression of C5aR (Fig. 7). In the LTA-stimulated group, the expression of C5aR changed significantly with the progression of the culture time and the continuation of stimulation (re-addition equal concentrations of LTA stimulant to each change). On the second day of stimulation, the expression of C5aR increased, and the gray value of the western blot band was almost 300,000, which was almost 3 -fold higher than that of the other groups, and the difference was statistically significant $(\mathrm{P}<0.05)$. No differences were observed in C5aR expression on days 1, 3, 5 and 7. In the LPS-stimulated group, with the progression of the culture time 
A

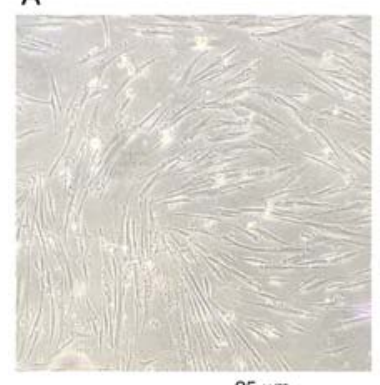

$25 \mu \mathrm{m}$

D

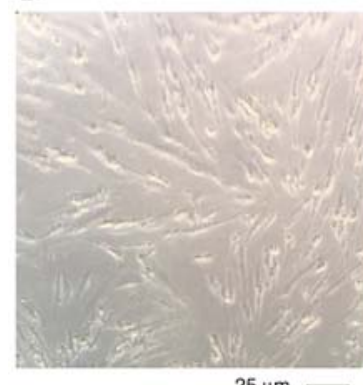

$25 \mu \mathrm{m}-$

G

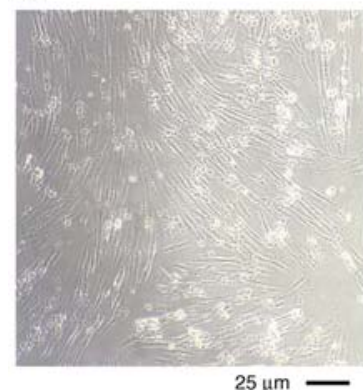

J

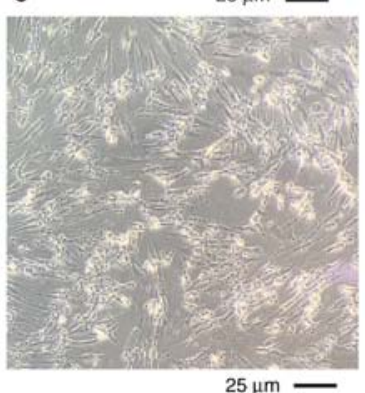

M

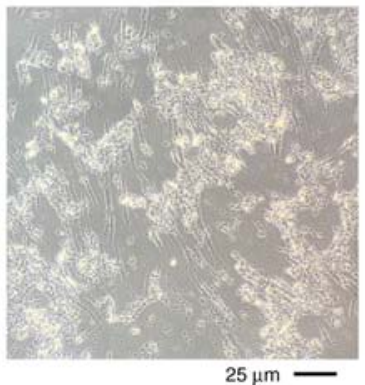

B



E

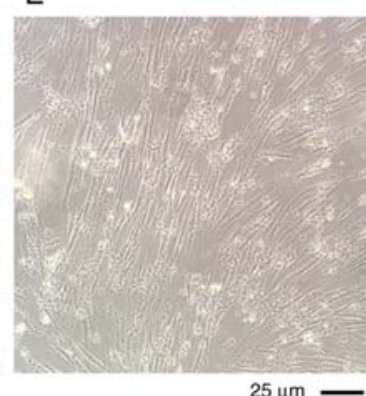

H

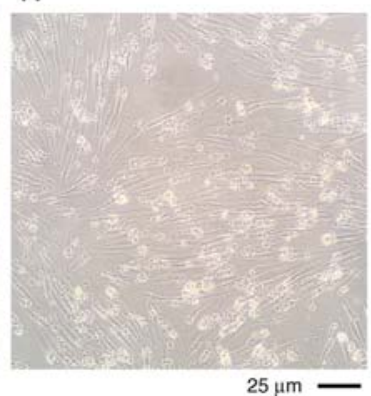

$\mathrm{K}$



N

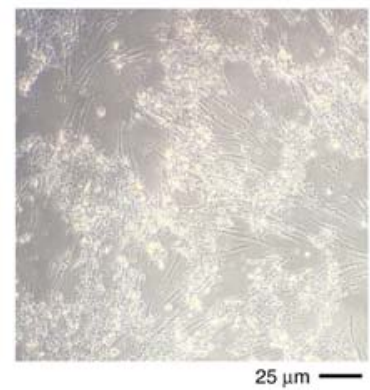

C

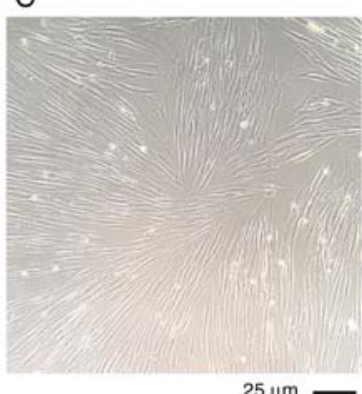

F

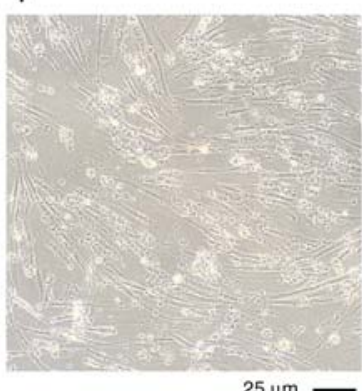

1

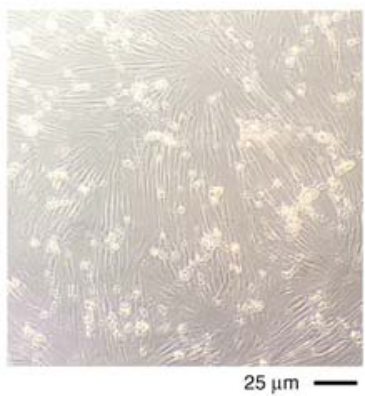

L

$25 \mu \mathrm{m}$

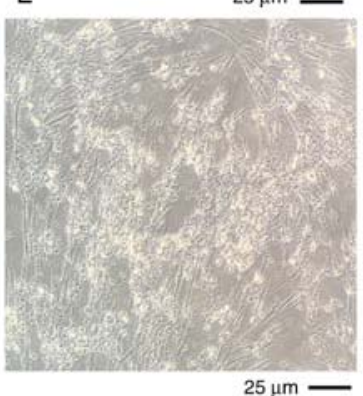

o

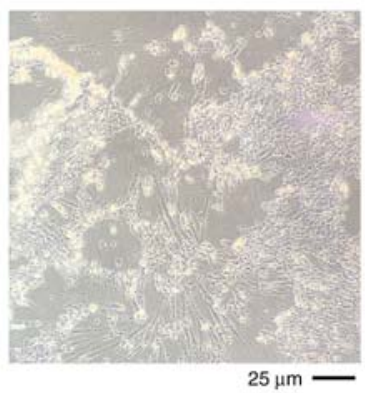

Figure 3. Morphological appearance of dental pulp cells stimulated with LTA and LPS at different time points. Cell morphology at day 1 following stimulation with (A) LTA, (B) LPS individually and (C) co-stimulation. Cells grew in good condition. Cell morphology at day 2 following stimulation with (D) LTA, (E) LPS individually and (F) co-stimulation. Cells grew in good condition, although cell shrinkage was observed. Cell morphology at day 3 following stimulation with (G) LTA, (H) LPS individually and (I) co-stimulation. More cell shrinkage was observed. Cell morphology at day 5 following stimulation with (J) LTA, (K) LPS individually and (L) co-stimulation. The growing status of cells decreased gradually. Cell morphology at day 7 following stimulation with (M) LTA, (N) LPS individually and (O) co-stimulation. Cells underwent severe shrinkage. Floating dead cells could be observed. LTA, lipoteichoic acid; LPS, lipopolysaccharide. 


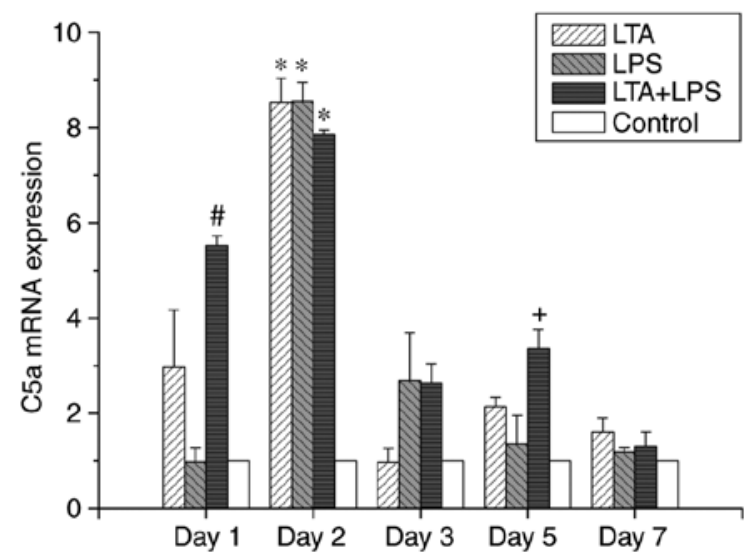

Figure 4. Relative expression levels of complement C5a mRNA at different time points detected by reverse transcription-quantitative polymerase chain reaction. Values were normalized to actin expression. ${ }^{*} \mathrm{P}<0.05$ vs. the corresponding group at other time points. ${ }^{~} \mathrm{P}<0.05$ vs. the LTA and LPS costimulation group at days 3 and $7 .^{+} \mathrm{P}<0.05$ vs. LTA and LPS co-stimulation group at days 3 and 7. LTA, lipoteichoic acid; LPS, lipopolysaccharide.

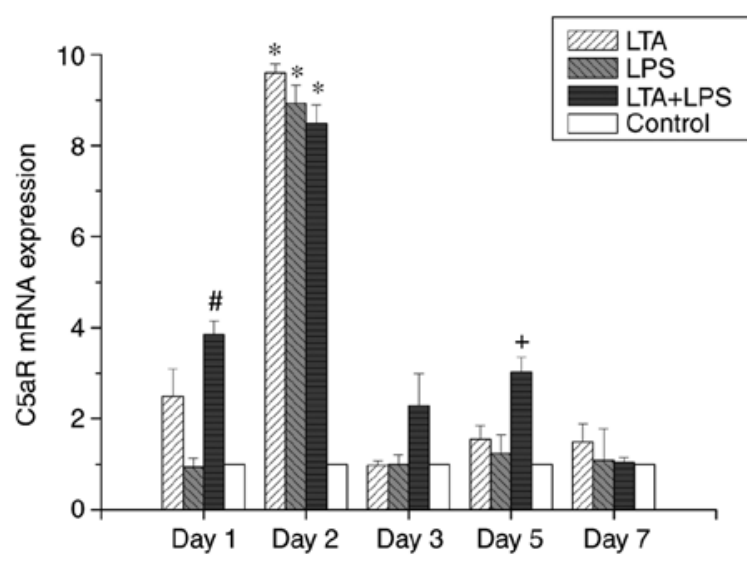

Figure 5. Relative expression levels of complement receptor C5aR mRNA at different time points detected by reverse transcription-quantitative polymerase chain reaction. Values were normalized to actin expression. ${ }^{*} \mathrm{P}<0.05$ vs. the corresponding group at other time points. ${ }^{~} \mathrm{P}<0.05$ vs. the LTA and LPS co-stimulation group $(\mathrm{A}+\mathrm{S})$ at days 3 and $7 .{ }^{+} \mathrm{P}<0.05$ vs. LTA and LPS co-stimulation group at days 3 and 7. LTA, lipoteichoic acid; LPS, lipopolysaccharide.

and the continuation of stimulation, the gray value of $\mathrm{C} 5 \mathrm{aR}$ expression on the second day was almost 300,000, which was almost 3-fold higher than that on the other days. The difference was statistically significant $(\mathrm{P}<0.05)$. Apart from the second day, no significant differences were observed in the expression of C5aR on the remaining days. In the LTA and LPS co-stimulated group, on the first day, the third day and the fifth day, the expression of C5aR was high, and the gray value of the western blot band was almost 250,000, which was higher than that of the seventh day. The difference was statistically significant $(\mathrm{P}<0.05)$.

Ultrastructural features of dental pulp cells. The ultrastructural features of the stimulated dental pulp cells are shown in Fig. 8. On the first day of stimulation, the number of lysosomes increased. The microvilli at the cell membrane were normal, indicating that the cell state was good, and the mito-

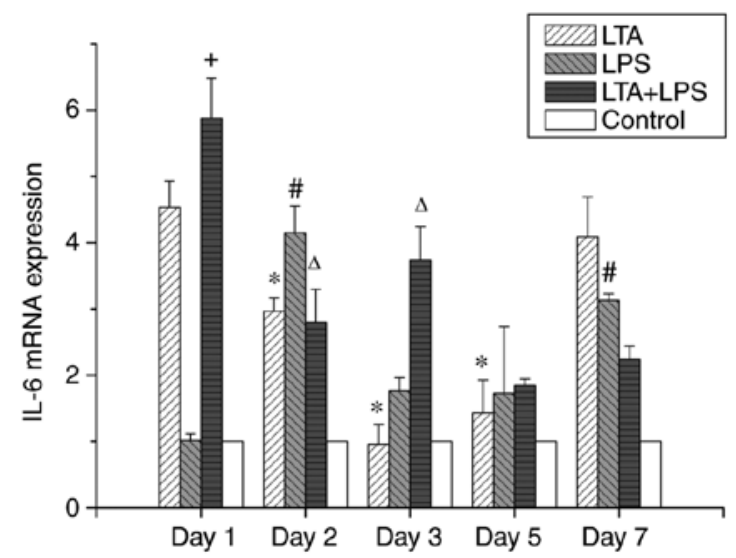

Figure 6. Relative mRNA expression levels of the inflammatory cytokine, IL-6, at different time points detected by reverse transcription-quantitative polymerase chain reaction. Values were normalized to actin expression. ${ }^{*} \mathrm{P}<0.05$ vs. the LTA group at days 1 and 7 . ${ }^{\#} \mathrm{P}<0.05$ vs. the LPS group at days 1,3 and $5 .{ }^{+} \mathrm{P}<0.05$ vs. the LTA and LPS co-stimulation group at days 2 , 3,5 and $7 .{ }^{\Delta} \mathrm{P}<0.05$ vs. LTA and LPS co-stimulation group at days 1,5 and 7 . LTA, lipoteichoic acid; LPS, lipopolysaccharide.

chondria and endoplasmic reticulum remained unaffected. Autophagy could be observed inside the cells (Fig. 8A). Following 2 days of stimulation, the cells were in good condition, but the number of microvilli were reduced (Fig. 8B). On the third day, the cell state was good, but there were more vacuoles. The numbers of microvilli were reduced, but the activity of cells was still good (Fig. 8C). On the fifth day, the cells were swelled and the cells were about to rupture and die (Fig. 8D). On the seventh day, necrotic cells were observable, with the nuclei in the middle, and the swollen cell edges were unclear (Fig. 8E). The control group displayed small mitochondria and cells were rich in endoplasmic reticulum, indicating that the cells were strong enough to synthesize protein. The ultrastructural features in the control group conformed to the characteristics of primary cells. Although the mitochondria were small and underdeveloped, they were numerous in number and displayed many glycogens. Maybe their energy metabolized through glycogen. The irregular karyotype may increase metabolic efficiency in order to increase the contact area with cytoplasm. The control groups at day 1 are shown in Fig. 8F, at day 2 in Fig. 8G, day 3 in Fig. 8H, day 5 in Fig. 8I, and at day 7 in Fig. 8J.

\section{Discussion}

It is well known that bacteria are closely related to the occurrence of caries. There are, broadly speaking, two different types of cell walls in bacteria, those of Gram-positive and those of Gram-negative bacteria. Pulpitis is mainly caused by bacterial infection, which is itself a secondary development of caries (tooth decay). LTA is a major constituent of the cell wall of Gram-positive bacteria. LPS occurs in the outer membrane of Gram-negative bacteria. In this study, LTA and LPS were used to stimulate human dental pulp cells, alone or in combination, in order to observe the immune response of dental pulp cells stimulated by foreign bacterial cell wall components, instead of using inflammatory factors directly to stimulate dental pulp cells. Current research indicates that cells can 


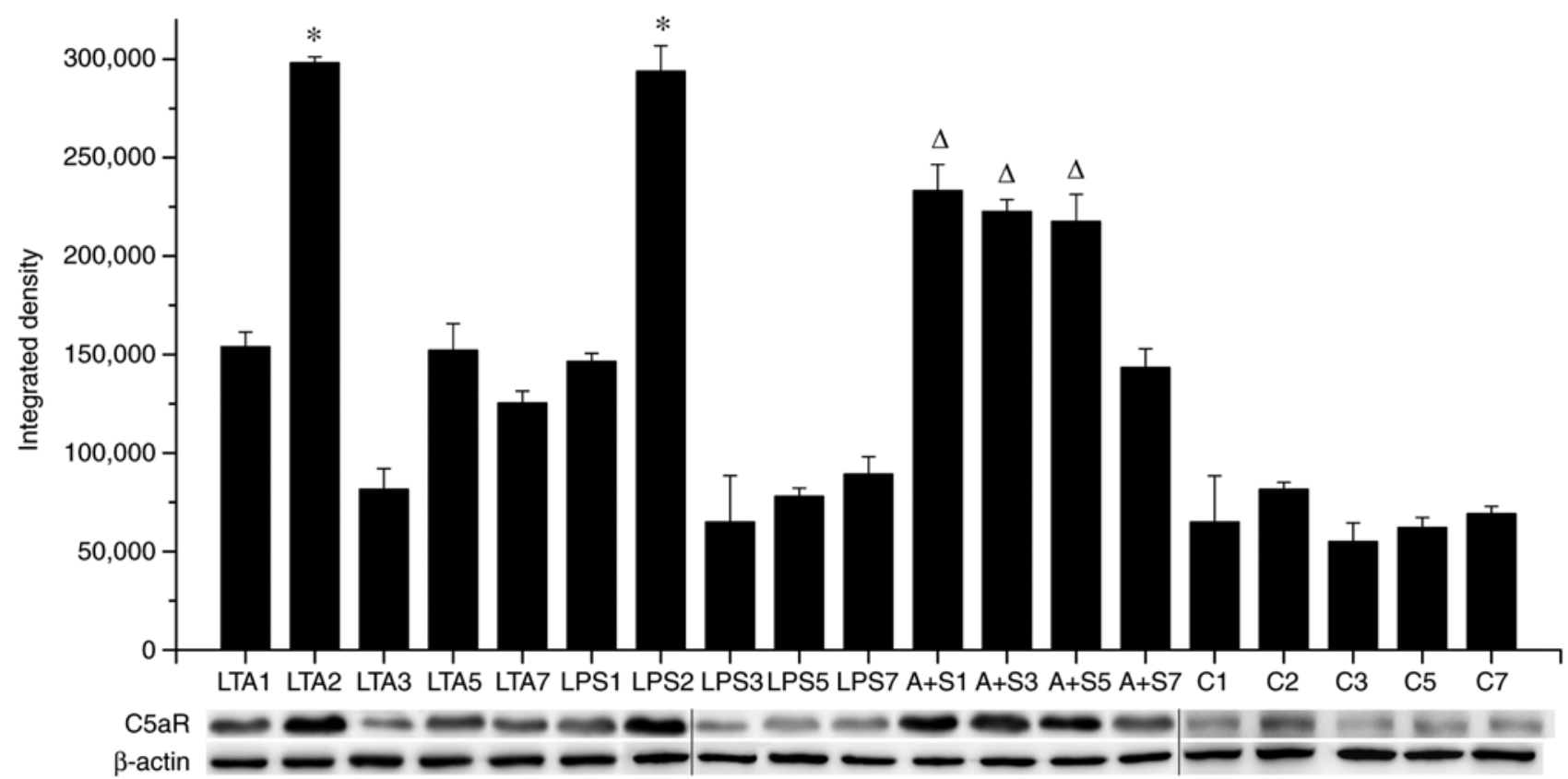

Figure 7. C5aR expression detected by western blot analysis at different time points. The results presented as the value calculated from three different cell samples, and each same cell sample assayed in triplicate. The numbers 1,3,5 and 7 written after LTA, LPS and A+S (LTA + LPS) indicate the number of days. $\mathrm{C}$ indicates the control group. Either $\mathrm{C} 5 \mathrm{aR}$ or actin bands were composited by 3 images which were derived from the same experiment under the same exposure. The images of C5aR/actin were composited and used line spacing between images. ${ }^{*} \mathrm{P}<0.05$ indicates that the expression of $\mathrm{C} 5 \mathrm{aR}$ at day 2 was different from that at the other time points. ${ }^{\Delta} \mathrm{P}<0.05$ indicates that the expression of $\mathrm{C} 5 \mathrm{aR}$ at days 1,3 and 5 was different from that at the other time points. LTA, lipoteichoic acid; LPS, lipopolysaccharide.

A

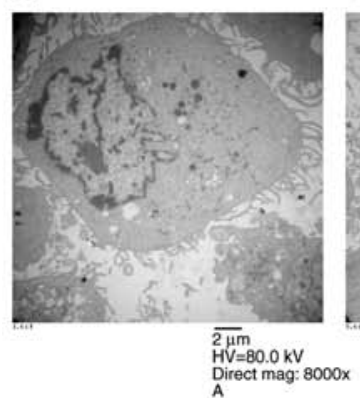

F



B

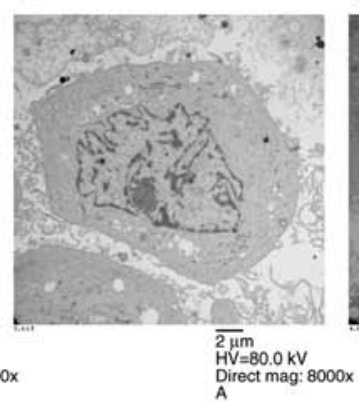

G

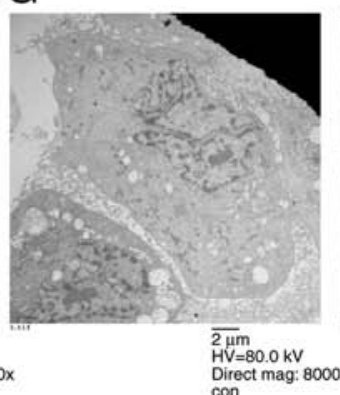

C

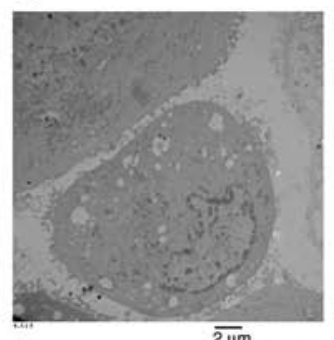

$\overline{\mathrm{i}} \overline{\mathrm{HV}}=80.0 \mathrm{kV}$ Direct mag: 8000

$\mathrm{H}$

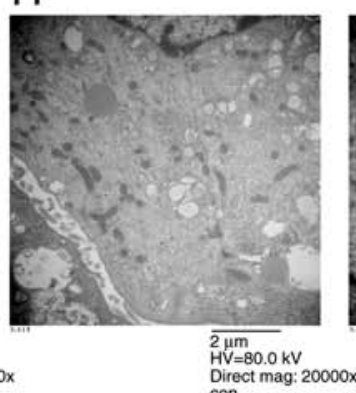

D

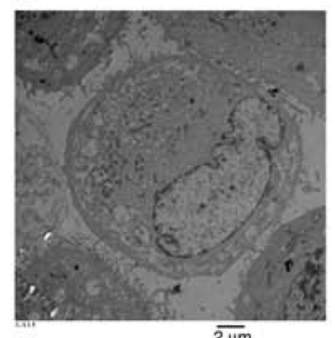

$\overline{\mathrm{Tm}}_{\mathrm{HV}=80.0 \mathrm{kV}}$ Direct mag: $8000 x$

I

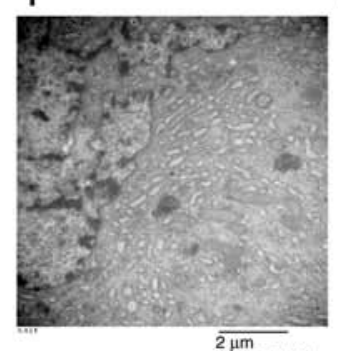

$\mathrm{HV}=80.0 \mathrm{kV}$
Direct mag: $20000 \mathrm{x}$
E

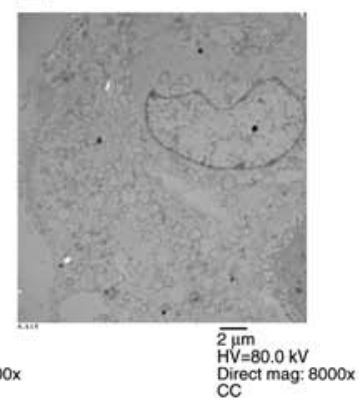

J

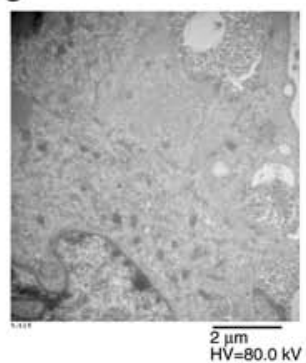

Direct mag: 20000

Figure 8. Ultrastructure of dental pulp cells. (A) The ultrastructure of dental pulp cells on the first day of stimulation. (B) The ultrastructure of dental pulp cells after 2 days of stimulation. (C) The ultrastructure of dental pulp cells on the third day of stimulation. (D) The ultrastructure of dental pulp cells on the fifth day of stimulation. (E) The ultrastructure of dental pulp cells on the seventh day of stimulation. (F) The ultrastructure of dental pulp cells in the control group at day 1. (G) The ultrastructure of dental pulp cells in the control group at day 2. (H) The ultrastructure of dental pulp cells in the control group at day 3. (I) The ultrastructure of dental pulp cells in the control group at day 5. (J) The ultrastructure of dental pulp cells in the control group at day 7. LTA, lipoteichoic acid; LPS, lipopolysaccharide.

only interact once they have accumulated. During the process of aggregation, the cellular microenvironment and 'soil' are formed, which are required for morphogenesis and survival.
Various factors interact into the network in this process (35). Therefore, in this study, fibroblasts and dental pulp stem cells in dental pulp cells were not isolated separately. We stimulated 
dental pulp cells directly to detect complement activation. After being stimulated by bacterial cell walls, immune-related cells in dental pulp cells secreted related inflammatory factors and signaled other immune cells to resist and kill foreign pathogenic bacteria. LTA and LPS are the best stimulators to study the activation of C5a by complement activation of dental pulp cells.

In this study, the results of RT-qPCR revealed that the expression of C5a mRNA in the LTA-stimulated group and the LPS-stimulated group were similar. In both these groups, there was a significant increase in C5a mRNA expression on the second day of stimulation, and the multiple was the same. This same multiple is an interesting result, showing that the expression of complement C5a mRNA was not high at the early stage of stimulation on dental pulp cells by LTA or LPS. With the progression of the experiment, C5a mRNA expression was higher, but was subsequently downregulated and remained at low levels. The reason for the decrease in C5a mRNA expression was that many immune cells die due to stimulation with LTA or LPS on the third day of culture. For this reason, other studies have stimulated cells with LTA or LPS only for $20 \mathrm{~min}$, or for only $24 \mathrm{~h}$ up to $48 \mathrm{~h}(32,34,35,37,40,42,45)$. Immune cells would die 3 days following LTA or LPS stimulation. In this study, the cells were stimulated for 7 days and were still in good condition. Although there were some dead cells, they could continue to be cultured. This indicated that dental pulp cells have a certain resistance. It is possible that immune cells inside the pulp died following stimulation, although there were some undifferentiated cells in the multicellular region of the pulp, which have the ability to differentiate into immune cells. Furthermore, it also showed the good vitality of dental pulp cells under stimulation.

When LTA and LPS were used to co-stimulate the human dental pulp cells, the expression of C5a increased on the first day, and its expression was 2-fold higher than that at 3 and 7 days. The reason for this may have been due to the more potent effect of LTA and LPS co-stimulation. Therefore, there must be a different response process of human dental pulp cells to co-stimulation. Similarly, mRNA expression was also high on the second day. Co-stimulation exhibited a distinctly different trend as regards C5a mRNA expression from stimulation with LTA or LPS alone. C5a mRNA expression increased only on the second day following single stimulation, and did not stimulate higher C5a mRNA expression with prolonged stimulation time. This indicated that under the condition of the simultaneous stimulation of LTA and LPS, undifferentiated cells in dental pulp cells may differentiate into immune cells, and the mRNA of small fragment C5a following complement activation was detected. Under the condition of single LTA or LPS stimulation, no such heightened expression occurs. There are three reasons for this: Firstly, a recently conducted study demonstrated that dental pulp tissue comprises a unique nonimmune cell type, the human pulp fibroblast, able to produce and efficiently activate the complement system proteins (35). Secondly, it may be due to the intense activity of stimulation. This study did not carry out experiments with longer stimulation times in culture, but C5a expression with the co-stimulation culture group may have been greater with thee extended culture time. Thirdly, it is well known that cell differentiation takes time. The time required to differentiate into different types of cells varies. For example, it takes 28 days for dental pulp stem cells to differentiate into osteoblasts, but only 14 days to differentiate into adipocytes. Therefore, the undifferentiated cells in the pulp need time to differentiate into immune cells after stimulation. The decrease in C5a mRNA expression on the seventh day of co-stimulation may be because the immune cells die after differentiation, or the secreted C5a is consumed.

$\mathrm{C} 5 \mathrm{aR}$ is a receptor for complement C5a, mainly expressed in neutrophils, basophils and monocytes. The results of RT-qPCR revealed that the expression trend of $\mathrm{C} 5 \mathrm{aR}$ in each group was identical to that of $\mathrm{C} 5 \mathrm{a}$, indicating the preciseness and reproducibility of the experiment. The expression of IL-6 mRNA in the LPS-stimulated group was low on the first day, then increased on the second day, which was 20-fold higher than that on the first day. The expression on the second day was consistent with the highest level in the LTA-stimulated group. The expression on the third day was again as low as that on the third day in the LTA-stimulated group. On the fifth day, IL-6 expression in each group remained at a low level. IL-6 expression slightly increased on the seventh day, but it was 2-fold lower than that on the first day. The expression of IL- 6 mRNA in the LTA-stimulated group was highest on the first day, then decreased with the progression of time. However, it increased on the seventh day, to levels similar to those observed on the first day. Although high expression levels of IL-6 mRNA were observed in both the LTA- and LPS-stimulated groups on the seventh day, they were both lower than those of the co-stimulated group on the first day. In addition, the high expression of IL-6 on the first day was 1.25-fold higher than that of LTA and LPS alone, which was consistent with the mRNA expression of C5a and C5aR, indicating the proinflammatory effect of LTA and LPS. In both the LTA- and LPS-stimulated groups, a rebound in IL-6 expression was observed on the seventh day, probably as undifferentiated cells in the pulpal cells may have differentiated into immune cells, thereby secreting inflammatory factors. It can be seen from the MTT and cell state figures that as the culture time was prolonged, the cell condition deteriorated and the number of dead cells increased. This was perhaps due to the stimulating factor, which are the cell wall components of Gram-positive and Gram-negative bacteria. The results revealed that the control group did not express IL-6 mRNA; however, the expression levels of C5a and C5aR mRNA were not low. As shown in Figs. 4 and 5, the expression levels of C5a and C5aR mRNA were not significantly higher in the LTA- and LPS-stimulated groups than in the control group at all time points, apart from day 2. A possible explanation may be that the immunoreaction of dental pulp cells first inhibits the expression of C5a mRNA, but the expression levels of C5a and C5aR mRNA were significantly elevated and higher than those of control group the following day. On the third day, most of the immune cells may have died due to the stimulation by LTA and LPS, and thus C5a and C5aR mRNA expression would both be low past the second day. That is why cells collected at 24 or $48 \mathrm{~h}$ following stimulation with LPS and LTA at a concentration of $1 \mu \mathrm{g} / \mathrm{ml}$ in other studies were still viable $(32,34,35,37,40,42,45)$. Our findings are consistent with those of these studies. The results of cell culture revealed that the cells remained in a good state until day 7 (Fig. 3). Under such a high concentration of LTA and LPS stimulation, dental pulp cells could survive to the seventh day with good 
activity, which was consistent with other reports of dental pulp cells. This experiment once again proved the high viability of dental pulp cells.

As mentioned above, although most immune cells may die on the third day, some undifferentiated cells still survive in the pulp, and can differentiate into immune cells following stimulation. This interpretation is made as IL-6 detection showed that there was an increase in IL-6 expression on the seventh day. Scanning electron microscopy also revealed some cell death in the late culture period, and the expression of C5a and C5aR may be decreased due to dead cells, while dead cells may cause the release of inflammatory factors, such as IL-6. Therefore, IL-6 expression was still high on the seventh day. Our experiment did not detect C5a expression by western blot, as upon the activation of the complement, a C5-converting enzyme is formed to cleave $\mathrm{C} 5$, which is the last enzymatic step in the complement cascade. C5 bound to $\mathrm{C} 3 \mathrm{~b}$ in $\mathrm{C} 5$ convertase, and was then cleaved into C5a and C5b. C5a is released into the liquid phase, and C5b still binds to the cell surface. Therefore, western blot analysis could not detect the expression of $\mathrm{C} 5 \mathrm{a}$.

In this study, the results of C5a and C5aR mRNA expression indicated that the extracted dental pulp cells had the ability to encode C5a and C5aR proteins without exogenous stimulation. This result is consistent with the descriptions in a previous study by the study group of I. About Chmilewsky et al (35) describing the expression of C5a in the LTA-free stimulation group and the control group by ELISA.

In summary, LTA and LPS stimulated the highest expression of C5a on the second day, and thus, we recommend the 48-h stimulation condition in the immunological study of dental pulp cells. From an inflammatory point of view, LPS is milder in the short time period of investigation. Others have reported that LTA induces a weaker inflammatory response than LPS. This may be related to the observation that gram-positive bacteria cause chronic mastitis more often than do Gram-negative infections (46). On the first day of observations, IL-6 mRNA expression was not high in the LPS stimulation group, although it was high in the LTA stimulation group. However, the expression in the LPS group increased the following day, which was 1.5 -fold higher than the level in the LTA group.

Subsequently, from the time progression data, on the third day and fifth day, all groups expressed low IL-6 mRNA levels, and these levels increased on the seventh day. This expression in the LTA stimulation group seemed stronger than that in the LPS stimulation group. The expression of IL-6 mRNA in the LTA group was approximately 1.5 -fold higher than that in the LPS group. Therefore, from the perspective of the full stimulation process, LTA stimulates a higher expression of IL-6 than does LPS, which indirectly indicates that the proinflammatory effect of LTA is stronger. From the observations of cell morphology and activity, the LPS group was superior to the LPS group in cell status and activity compared to the LPS group (Fig. 3). As for the inflammation of the LTA and LPS combined stimulation group, it is clear that cell condition was worse than that of the LTA and LPS single stimulation groups, as expected (Fig. 3). Stimulation by LTA differs from that by LPS, with a differential expression of inflammatory factors, particularly in the timeline used in this study. While the different expression of inflammatory factors indicated the different effect of LTA and LPS stimulation. As we well known, different types of bacteria have different functions on dental inflammatory diseases. This suggests that the dominant bacteria in the case of inflammatory pulp are related to the occurrence and development of rickets. As the results mentioned above have shown, if LPS are the dominant bacteria, this would lead to a higher expression of inflammatory factors, such as IL-6, thus easily causing the inflammation of the pulp. Further research is required to verify the correlation of pulpitis and Gram-negative/positive bacteria. However, this study demonstrated the differences in IL-6 expression following stimulation with LTA and LPS.

Clinically, Gram-negative bacteria play a role in the formation of cavities. The pathogenic bacteria involved in pulp inflammation are more severe. The results of this study are consistent with these observations. In conclusion, a concentration of $1 \mu \mathrm{g} / \mathrm{ml}$ of LTA and LPS stimulated human dental pulp cells to activate the expression of complement C5a, and the expression of C5a was the highest at $48 \mathrm{~h}$. However, further research is warranted to confirm the findings of this study. It would be of interest to determine why C5a is express at low levels along with the progression of the stimulation process, as well as whether C5a can promote the dental pulp cells differentiate into odontoblasts. It would also be of interest to examine how to use the high expression of C5a in the differentiation process of dental pulp cells. In the future, we hope to use the immune reaction of dental pulp cells, in order to develop therapeutic means of combating the bacteria involved in caries. The development of methods with which to help pulp cells to protect themselves and to avoid caries would perhaps prevent the development of irreversible pulpitis.

\section{Acknowledgements}

The authors are grateful to the Key Laboratory of Myocardial Ischemia of the Ministry of Education (The Second Affiliated Hospital of Harbin Medical University, Harbin, China) for providing facilities to conduct the investigations of the present study. In addition, the authors are grateful to the office of Scientific Writing of University of Tennessee Health Science Center for language editing.

\section{Funding}

The present study was supported by the Heilongjiang Natural Science Foundation of China under contract No. QC2015104, the Health and Family Planning Commission of Heilongjiang province. (grant no. 2017-097) and Heilongjiang Academy of Medical Science (grant no. 201703).

\section{Availability of data and materials}

The datasets used and/or analyzed during the current study are available from the corresponding author on reasonable request.

\section{Authors' contributions}

ML designed the study, performed the experiments and wrote the manuscript. HM performed the experiments and organized 
the images. WP and $\mathrm{LZ}$ participated in this experiment and made substantial contributions to the acquisition of data. ZJ analyzed and interpreted the data. WH and LG organized the images, interpreted the data, and were involved in drafting the manuscript. XC performed the surgery to obtain the teeth and was involved in revising the manuscript. NL and JH helped write the manuscript, and were responsible for the study funding, and in the conception and design of the study, as well as providing final approval of the version to be published. All authors have read and approved the final manuscript.

\section{Ethics approval and consent to participate}

The present study was approved by the Institutional Ethics Committee of The Second Affiliated Hospital of Harbin Medical University (Harbin, China). Written informed consent was obtained from all patients.

\section{Patient consent for publication}

Not applicable.

\section{Competing interests}

The authors declare that they have no competing interests.

\section{References}

1. Aurrekoetxea M, Garcia-Gallastegui P, Irastorza I, Luzuriaga J, Uribe-Etxebarria V, Unda F and Ibarretxe G: Dental pulp stem cells as a multifaceted tool for bioengineering and the regeneration of craniomaxillofacial tissues. Front Physiol 6: 289, 2015.

2. Liu M, Sun Y, Liu Y, Yuan M, Zhang Z and Hu W: Modulation of the differentiation of dental pulp stem cells by different concentrations of $\beta$-glycerophosphate. Molecules 17: 1219-1232, 2012.

3. Franzon R, Gomes M, Pitoni CM, Bergmann CP and Araujo FB Dentin rehardening after indirect pulp treatment in primary teeth. J Dent Child (Chic) 76: 223-228, 2009.

4. Mathur VP, Dhillon JK, Logani A and Kalra G: Evaluation of indirect pulp capping using three different materials: A randomized control trial using cone-beam computed tomography. Indian J Dent Res 27: 623-629, 2016.

5. Petrou MA, Alhamoui FA, Welk A, Altarabulsi MB, Alkilzy M and $\mathrm{H}$ Splieth C: A randomized clinical trial on the use of medical Portland cement, MTA and calcium hydroxide in indirect pulp treatment. Clin Oral Investig 18: 1383-1389, 2014.

6. Ohnishi T, Bandow K, Kakimoto K, Kusuyama J and Matsuguchi T: Long-time treatment by low-dose N-acetyl-Lcysteine enhances proinflammatory cytokine expressions in LPS-stimulated macrophages. PLoS One 9: e87229, 2014.

7. van Beek J, Elward K and Gasque P: Activation of complement in the central nervous system: Roles in neurodegeneration and neuroprotection. Ann N Y Acad Sci 992: 56-71, 2003.

8. Baumann U, Chouchakova N, Gewecke B, Köhl J, Carroll MC, Schmidt RE and Gessner JE: Distinct tissue site-specific requirements of mast cells and complement components $\mathrm{C} 3 / \mathrm{C} 5 \mathrm{a}$ receptor in $\mathrm{IgG}$ immune complex-induced injury of skin and lung. J Immunol 167: 1022-1027, 2001.

9. Bürgi B, Brunner T and Dahinden CA: The degradation product of the C5a anaphylatoxin C5adesarg retains basophil-activating properties. Eur J Immunol 24: 1583-1589, 1994.

10. Drouin SM, Kildsgaard J, Haviland J, Zabner J, Jia HP, McCray PB Jr, Tack BF and Wetsel RA: Expression of the complement anaphylatoxin $\mathrm{C} 3 \mathrm{a}$ and $\mathrm{C} 5 \mathrm{a}$ receptors on bronchial epithelial and smooth muscle cells in models of sepsis and asthma. J Immunol 166: 2025-2032, 2001.

11. el-Lati SG, Dahinden CA and Church MK: Complement peptides C3a- and C5a-induced mediator release from dissociated human skin mast cells. J Invest Dermatol 102: 803-806, 1994.
12. Elsner J, Oppermann M, Czech W, Dobos G, Schöpf E, Norgauer $\mathrm{J}$ and Kapp A: C3a activates reactive oxygen radical species production and intracellular calcium transients in human eosinophils. Eur J Immunol 24: 518-522, 1994.

13. Nilsson G, Johnell M, Hammer CH, Tiffany HL, Nilsson K, Metcalfe DD, Siegbahn A and Murphy PM: C3a and C5a are chemotaxins for human mast cells and act through distinct receptors via a pertussis toxin-sensitive signal transduction pathway. J Immunol 157: 1693-1698, 1996.

14. Schulman ES, Post TJ, Henson PM and Giclas PC: Differential effects of the complement peptides, C5a and C5a des Arg on human basophil and lung mast cell histamine release. J Clin Invest 81: 918-923, 1988.

15. Vogt W: Anaphylatoxins: Possible roles in disease. Complement 3: $177-188,1986$.

16. Pan H, Shen Z, Mukhopadhyay P, Wang H, Pacher P, Qin X and Gao B: Anaphylatoxin C5a contributes to the pathogenesis of cisplatin-induced nephrotoxicity. Am J Physiol Renal Physiol 296: F496-F504, 2009.

17. Conway EM, Van de Wouwer M, Pollefeyt S, Jurk K, Van Aken H, De Vriese A, Weitz JI, Weiler H, Hellings PW, Schaeffer P, et al: The lectin-like domain of thrombomodulin confers protection from neutrophil-mediated tissue damage by suppressing adhesion molecule expression via nuclear factor kappaB and mitogenactivated protein kinase pathways. J Exp Med 196: 565-77, 2002.

18. Van de Wouwer M, Plaisance S, De Vriese A, Waelkens E, Collen D, Persson J, Daha MR and Conway EM: The lectinlike domain of thrombomodulin interferes with complement activation and protects against arthritis. J Thromb Haemost 4: 1813-1824, 2006

19. Boshra H, Peters R, Li J and Sunyer JO: Production of recombinant C5a from rainbow trout (Oncorhynchus mykiss): Role in leucocyte chemotaxis and respiratory burst. Fish Shellfish Immunol 17: 293-303, 2004.

20. Flierl MA, Perl M, Rittirsch D, Bartl C, Schreiber H, Fleig V, Schlaf G, Liener U, Brueckner UB, Gebhard F and Huber-Lang MS: The role of C5a in the innate immune response after experimental blunt chest trauma. Shock 29: 25-31, 2008.

21. Gressner OA, Koch A, Sanson E, Trautwein C and Tacke F: High C5a levels are associated with increased mortality in sepsis patients-no enhancing effect by actin-free Gc-globulin. Clin Biochem 41: 974-980, 2008.

22. Guo RF and Ward PA: Role of C5a in inflammatory responses. Annu Rev Immunol 23: 821-852, 3005.

23. Marigo I, Dolcetti L, Serafini P, Zanovello P and Bronte V: Tumor-induced tolerance and immune suppression by myeloid derived suppressor cells. Immunol Rev 222: 162-179, 2008.

24. Széplaki G, Varga L, Füst G and Prohászka Z: Role of complement in the pathomechanism of atherosclerotic vascular diseases. Mol Immunol 46: 2784-2793, 2009.

25. Hornum L, Hansen AJ, Tornehave D, Fjording MS, Colmenero P, Wätjen IF, Søe Nielsen NH, Bliddal H and Bartels EM: C5a and $\mathrm{C} 5 \mathrm{aR}$ are elevated in joints of rheumatoid and psoriatic arthritis patients, and C5aR blockade attenuates leukocyte migration to synovial fluid. PLoS One 12: e0189017, 2017.

26. Russkamp NF, Ruemmler R, Roewe J, Moore BB, Ward PA and Bosmann M: Experimental design of complement component 5a-induced acute lung injury (C5a-ALI): A role of CC-chemokine receptor type 5 during immune activation by anaphylatoxin. FASEB J 29: 3762-3772, 2015.

27. Wang R, Xiao H, Guo R, Li Y and Shen B: The role of C5a in acute lung injury induced by highly pathogenic viral infections. Emerg Microbes Infect 4: e28, 2015.

28. Michalopoulos GK and DeFrances MC: Liver regeneration. Science 276: 60-66, 1997.

29. Mastellos D, Papadimitriou JC, Franchini S, Tsonis PA and Lambris JD: A novel role of complement: Mice deficient in the fifth component of complement (C5) exhibit impaired liver regeneration. J Immunol 166: 2479-2486, 2001.

30. Lara-Astiaso D, Izarra A, Estrada JC, Albo C, Moscoso I, Samper E, Moncayo J, Solano A, Bernad A and Díez-Juan A: Complement anaphylatoxins $\mathrm{C} 3 \mathrm{a}$ and $\mathrm{C} 5 \mathrm{a}$ induce a failing regenerative program in cardiac resident cells. Evidence of a role for cardiac resident stem cells other than cardiomyocyte renewal. Springerplus 1: 63, 2012.

31. Ignatius A, Ehrnthaller C, Brenner RE, Kreja L, Schoengraf $P$, Lisson P, Blakytny R, Recknagel S, Claes L, Gebhard F, et al: The anaphylatoxin receptor $\mathrm{C} 5 \mathrm{aR}$ is present during fracture healing in rats and mediates osteoblast migration in vitro. $\mathrm{J}$ Trauma 71 : 952-960, 2011. 
32. Chmilewsky F, Ayaz W, Appiah J, About I and Chung SH: Nerve growth factor secretion from pulp fibroblasts is modulated by complement C5a receptor and implied in neurite outgrowth. Sci Rep 6: 31799, 2016.

33. Chmilewsky F, Jeanneau C, Dejou J and About I: Sources of dentin-pulp regeneration signals and their modulation by the local microenvironment. J Endod 40 (Suppl 4): S19-S25, 2014.

34. Chmilewsky F, Jeanneau C, Laurent P and About I: Pulp fibroblasts synthesize functional complement proteins involved in initiating dentin-pulp regeneration. Am J Pathol 184: 1991-2000, 2014.

35. Chmilewsky F, Jeanneau C, Laurent P and About I: LPS induces pulp progenitor cell recruitment via complement activation. J Dent Res 94: 166-174, 2015.

36. Chmilewsky F, Jeanneau C, Laurent P, Kirschfink $M$ and About I: Pulp progenitor cell recruitment is selectively guided by a C5a gradient. J Dent Res 92: 532-539, 2013.

37. Jeanneau C, Rufas P, Rombouts C, Giraud T, Dejou J and About I: Can pulp fibroblasts kill cariogenic bacteria? Role of complement activation. J Dent Res 94: 1765-1772, 2015.

38. Kidd EA and Fejerskov O: What constitutes dental caries? Histopathology of carious enamel and dentin related to the action of cariogenic biofilms. J Dent Res 83: C35-C38, 2004.

39. Section On Oral Health: Maintaining and improving the oral health of young children. Pediatrics 134: 1224-1229, 2014.

40. Jiang W, Lv H, Wang H, Wang D, Sun S, Jia Q, Wang P, Song B and Ni L: Activation of the NLRP3/caspase-1 inflammasome in human dental pulp tissue and human dental pulp fibroblasts. Cell Tissue Res 361: 541-555, 2015.
41. Koch L, Frommhold D, Buschmann K, Kuss N, Poeschl J and Ruef P: LPS- and LTA-induced expression of IL- 6 and TNF- $\alpha$ in neonatal and adult blood: role of MAPKs and NF- $\mathrm{kB}$. Mediators Inflamm 2014: 283126, 2014.

42. Wisithphrom K, Murray PE and Windsor LJ: Interleukin-1 alpha alters the expression of matrix metalloproteinases and collagen degradation by pulp fibroblasts. J Endod 32: 186-192, 2006.

43. Elsalhy M, Azizieh F and Raghupathy R: Cytokines as diagnostic markers of pulpal inflammation. Int Endod J 46: 573-580, 2013.

44. Livak KJ and Schmittgen TD: Analysis of relative gene expression data using real-time quantitative PCR and the 2(-Delta Delta C(T)) method. Methods 25: 402-408, 2001.

45. Abd-Elmeguid A, Yu DC, Kline LW, Moqbel R and Vliagoftis $\mathrm{H}$ : Dentin matrix protein-1 activates dental pulp fibroblasts. J Endod 38: 75-80, 2012.

46. Bulgari O, Dong X, Roca AL, Caroli AM and Loor JJ: Innate immune responses induced by lipopolysaccharide and lipoteichoic acid in primary goat mammary epithelial cells. J Anim Sci Biotechnol 8: 29, 2017.

This work is licensed under a Creative Commons Attribution-NonCommercial-NoDerivatives 4.0 International (CC BY-NC-ND 4.0) License. 